\title{
Acyl-CoA Binding Protein (ACBP) Encoding Gene the Relationship Between Expression Analysis and Different Conditions in Onychostoma Macrolepis
}

\author{
Xiaofei Yang, Shaogang Xu, Wentong Li, Shiquan Ma, and Guiqiang Yang
}

\begin{abstract}
One Acyl-CoA binding protein(ACBP) encoding gene was isolated from testis of Onychostoma macrolepis using homologous cloning and the RACE method. The full $O m a-A C B P$ cDNA(GenBank accession no: JN254628) was 503 bp long and comprised 37 bp of the $5^{\prime}$-Untranslated Regions(UTR), $267 \mathrm{bp}$ of the coding sequence(CDS) encoding a 88 amino acid proteins, and 199 bp of the 3'- Untranslated Regions(UTR) with the polyA tail. A condensed phylogenetic tree show that $O m a-A C B P$ had similarities with vasas of fish species and even mammal and amphibian species, The Oma-ACBP shared $92 \%$ sequenced identity with Cyprinus carpio and $91 \%$ with Carassius auratus, including a conserved FABP domain, the result enriches our understanding in the study of sequence classification in Onychostoma macrolepis. The Quantitative real-time PCR analysis demonstrated that $O m a-A C B P$ was highly expressed in intestine, spleen and liver, but weakly in testis, ovary, heart, brain, cheek, muscle and eye. It was highly expressed in liver and spleen $(42 \%$ of dietary protein), weakly expressed in intestine (52\% of dietary protein). In starvation challenge, the expression was weakly expressed from 5 day to 8 day, and highly expressed from 3 day to 5 day, and the expression kept stabilizing until the end of the experiment.
\end{abstract}

Index Terms-ACBP, onychostoma macrolepis, cloning, qRT-PCR, expression.

\section{INTRODUCTION}

Acyl-CoA binding protein (ACBP) was known as diazepam binding inhibitor(DBI)/endozepine(EP), is a highly conserved, approximately $10 \mathrm{kDa}$ cytosolic protein [1]. ACBP binds saturated and unsaturated C14-C22 acyl-CoA esters in a one-to-one binding mode with high specificity and affinity $\left(\mathrm{Kd}=2^{\wedge} 10 \mathrm{~nm}\right) \quad$ [2]. Acyl-CoA-binding protein (ACBP) is involved in lipid metabolism, ACBP plays a key role in multiple cellular tasks including modulation of fatty acid biosynthesis, enzyme regulation, and gene regulation [3]-[5]. ACBP is also apparently involved in fatty acid elongation, sphingolipid synthesis, protein sorting and vesicle traffic [6]-[8]. In mammals, ACBP was first characterized in liver(L-ACBP), homologous distinct ACBP genes have been identified in testes(T-ACBP) [9] and

Manuscript received April 10, 2013; revised July 11, 2013. This work was supported in part by the Beijing Municipal Science \& Technology Commission under Grant Z090605006009015.

Xiaofei Yang, Shaogang Xu, Wentong Li, and Guiqiang Yang are with the Beijing fisheries research institute, Beijing, CO 100068 China (e-mail: xushaogang@bjfishery.com)

Shiquan Ma is with the Science and Technology Commission of Huairou District, Beijing, CO 100000 China.
brain(B-ACBP) [10].

Now, the ACBP has been identified in many fishes, such as ematostella vectensis [11], Danio rerio [12], Ictalurus punctatus [13], Oncorhynchus mykiss, Salmo salar and Cyprinus carpio were submitted to Genbank in the aquatic animals(http://www.ncbi.nlm.nih.gov). Sequence analysis comparisons suggest that ACBP is highly conserved across fish species in protein sequence. The largescale shoveljaw fish (Onychostoma macrolepis) is an omnivorous species belonging to the family Cyprinidae, it is a valuable wild species [14]. However, no data is available on the ACBP and its expression of Onychostoma macrolepis. In the present study, in order to clarify the role of the ACBP in energy metabolism, we isolated the cDNA and characterized the expression of ACBP in the tissues, starvation and dietary challenge.

\section{MATERIALS AND METHODS}

\section{A. Materials Collection}

Largescale shoveljaw fish(Onychostoma macrolepis) $21 \pm 4 \mathrm{~g}$ in body weight, $12.3 \pm 3.2 \mathrm{~cm}$ in body lengh, were obtained from National Engineering Research Center for Freshwater Fisheries in Fangshan District(Beijing, China), reared in $0.2 \mathrm{~m}^{3}$ class tanks and temperature $\left(19-22^{\circ} \mathrm{C}\right)$ were maintained at the same levels. Fishes were held for a week to adjust to the temperature and environment conditions, and were fed four times daily with common fish feed.

\section{B. Dietary and Starvation Challenge Experiment}

For the study of ACBP in tissues, the testis, ovary, liver, heart, brain, cheek, intestine, muscle, eye and spleen were collected from the mature fish. In dietary challenge experiment, two levels of dietary protein( $42 \%$ and 52\%) were set, the fish was put in twelve sets of four class tanks that were controlled at the same temperature and environment conditions, 20 fish are in each tanks. Following the 12-week feeding, the liver, intestine and spleen were maintained in a concrete condition until 5-hour post-feed, the diet of Tubifex(Limnodrilus hoffmeisteri) as the control group. In the starvation challenge experiments, three fishes from each group, and the liver were collected at $0,1,2,3,4,5$, $6,7,8,9,10,11,12,13$ and 14day post-starvation from the fishes. All of samples were snap frozen in liquid nitrogen, and stored at $-80^{\circ} \mathrm{C}$ until use.

\section{RNA Extraction}

Tissue species were homogenated by IKA-T10 
Homogenizer (IKA, Staufen, Germany). Total RNAs from different tissues were extracted by the RNAprep Kit (Tiangen, Beijing, China) technique following the manufacturer's instructions and preserved for quantitative real-time PCR. Purity and integrity was assessed by the A260/280 nm ratio using Smart spec $^{\mathrm{TM}}$ plus spectrophotometer (BioRad, Hercules, USA) and integrity on a $1.2 \%$ agarose gel.

\section{Isolation of a cDNA Encoding Oma-ACBP by PCR}

First-strand cDNA synthesis was performed by Reverse Transcriptase kit (TaKaRa, Dalian, China). First strand cDNA was generated in a $25 \mu \mathrm{l}$ reaction volume containing, $500 \mathrm{ng}$ total RNA, $5 \times$ PrimeScript Buffer, $50 \mu \mathrm{M}$ oligodT Primer, $100 \mu \mathrm{M}$ Random 6 mers, PrimeScript RT Enzyme Mix I, the reaction was conducted at $37^{\circ} \mathrm{C}$ for $15 \mathrm{~min}$ and $85^{\circ} \mathrm{C}$ for $5 \mathrm{sec}$. Specific primer pairs were designed based on the sequence available in NCBI to amplify a cDNA fragment of approximately $155 \mathrm{bp}$ from testis (Fig. 1 and Fig. 2). PCR was performed under the following conditions: denaturation at at $94^{\circ} \mathrm{C}$ for $3 \mathrm{~min}$, followed by 40 cycles of $30 \mathrm{sec}$ at $94^{\circ} \mathrm{C}$, $30 \mathrm{sec}$ at $55^{\circ} \mathrm{C}, 2 \mathrm{~min}$ at $72^{\circ} \mathrm{C}$, final extension of $7 \mathrm{~min}$ at $72^{\circ} \mathrm{C}$, using a Eppendorf PCR cycler (Eppendorf, Germany). The RACE method was used to obtain the full lenth $O m a-A C B P$ sequence by using BD SMART RACE Kit (Clontech, Carlsbad, USA). PCR products were analyzed on a $1.2 \%$ agarose gels, the amplified fragments were separated and purified with AxyPrep ${ }^{\mathrm{TM}}$ DNA Gel Extraction Kit(Axygen, Hangzhou, China) then cloned into the pMD18-T cloning vector(Takara Dalian China). Plasmids containing the insert were purified with minipreps from AxyPrep ${ }^{\mathrm{TM}}$ Plasmid Kits(Axygen, Hangzhou, China). The RT-PCR clones were randomly picked, and were sequenced by Tsingke BioTech company(Tsingke, Beijing, China).

\begin{tabular}{|c|c|c|c|}
\hline Primers & Sequence $\left(5^{\prime} \rightarrow 3^{\prime}\right)$ & $\begin{array}{l}\text { Positio } \\
\mathrm{n}\end{array}$ & $\begin{array}{l}\text { Product( } \\
\text { bp) }\end{array}$ \\
\hline \multicolumn{4}{|c|}{ For the cloning of conserved sequence } \\
\hline PF1 & $\begin{array}{l}\text { AAAGCAGCAGAGGAGG } \\
\mathrm{T}\end{array}$ & $59-155$ & 155 \\
\hline PR1 & CAAGCTTCCCATTTGGC & & \\
\hline \multicolumn{4}{|c|}{ For the cloning of 3' end RACE and 5' end RACE } \\
\hline P3RACE- & GACCGGGCATGTTAGA & $168-50$ & 336 \\
\hline 1 & TTTCAC & 3 & \\
\hline $\begin{array}{l}\text { P3RACE- } \\
2\end{array}$ & $\begin{array}{l}\text { TCAGAAAGCAGCAGAG } \\
\text { GAGGTC }\end{array}$ & $55-503$ & 449 \\
\hline $\begin{array}{l}\text { P5RACE- } \\
1\end{array}$ & $\begin{array}{l}\text { CGTCTGATGGTTTCGCT } \\
\text { TTC }\end{array}$ & $1-85$ & 104 \\
\hline $\begin{array}{l}\text { P5RACE- } \\
2\end{array}$ & $\begin{array}{l}\text { GCCTTGCCAGTGAAATC } \\
\text { TAAC }\end{array}$ & $1-178$ & 198 \\
\hline \multicolumn{4}{|c|}{ Primers used for quantitative real-time PCR } \\
\hline $\mathrm{P}-\mathrm{QF}$ & $\begin{array}{l}\text { TCAGAAAGCAGCAGAG } \\
\text { GAGG }\end{array}$ & $55-198$ & 144 \\
\hline $\mathrm{P}-\mathrm{QR}$ & $\begin{array}{l}\text { GCCTTGCCAGTGAAATC } \\
\text { TAAC }\end{array}$ & & \\
\hline actinF & $\begin{array}{l}\text { TCСССТСААТСССАААG } \\
\text { СС }\end{array}$ & & 121 \\
\hline actinR & $\begin{array}{l}\text { GGAGTCCATCACGATA } \\
\text { CCAGT }\end{array}$ & & \\
\hline
\end{tabular}

Fig. 1. Oma-ACBP and $\beta$-actin genes, Corresponding PCR primers used for gene fragment cloning and quantitative real time PCR.

\section{E. Phylogenetic Analysis of Oma-ACBP}

The PCR, RACE and quantitative real-time PCR primers were designed using Primer Premier 5(PREMIER Biosoft, Palo Alto, USA). Similarity analysis was performed with Blastn(http://www.ncbi.nlm.nih.gov/). Gene transla- tion and prediction of the deduced protein were performed with Open Reading Frame Finder (ORF Finder, http://www. ncbi.nlm.nih.gov/gorf/gorf.html). Sequence assembly was performed using DNAman software (Lynnon Biosoft). The Molecular Evolution Genetics Analysis (MEGA) version 4.0 and Clustal $\mathrm{X}$ were used to construct a phylogenetic tree using the neighbor-joining method. Quantitative data were expressed as means \pm SD (standard deviation).

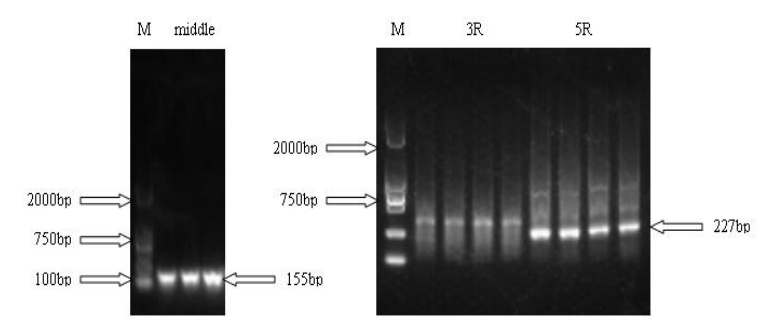

Fig. 2. Electrophoresis of the Oma-ACBP PCR products by primers PF1 and PR1 (middle), M (marker), 3' RACE(3R) and 5' RACE(5R).

\section{F. Quantitative Real-Time PCR Assay}

Total RNAs were isolated from the different tissues of fish. First strand cDNA was synthesized and stored at $-20^{\circ} \mathrm{C}$ until used for real-time PCR, using PrimeScript ${ }^{\circledR} \mathrm{RT}$ Enzyme (Takara, Dalian, China). The first strand cDNA was synthesized as described above and stored at $-20^{\circ} \mathrm{C}$ until used for real-time-PCR. The mRNA expression of $O m a-A C B P$ in different tissues was measured by real-time $\mathrm{PCR}$, the real-time primers were designed based on the cloned Oma-ACBP (Genbank accession: JN254628).

A pairs primers (P-QF and $\mathrm{P}-\mathrm{QR}$ ) were used to amplify a PCR product, The $\beta$-actin was used as a reference gene for internal standardization with the primers actinF and actinR (Fig.1). The qRT-PCR was performed in a volume of $20 \mu \mathrm{l}$ containing $10 \mu \mathrm{l} 2 \times$ SYBR Premix Ex Taq, $0.4 \mu \mathrm{l}$ ROX, $6 \mu \mathrm{l}$ DNase-RNase free water (Takara Dalian China), 2 ul cDNA, $0.8 \mu \mathrm{l}$ each of $10 \mu \mathrm{M}$ forward and reverse primer, Quantitative real-time PCR(qRT-PCR) was performed in a Funglyn FTC-3000 real-time cycler (Funglyn Biotech, Toronto, Canada). Dissociation melting curves analysis of amplification products were performed at the end reaction to confirm that primer-dimers and nonspecific amplification was not detected. The relative quantification between ACBP and $\beta$-actin were calculated using the comparative CT method.

cDNA of each sample from the experiment fishes were used for analysis in real-time PCR, the $\beta$-actin transcript levels were used to normalize samples. The real-time standard curve of each gene was prepared using the $O m a-A C B P$ cDNA as a template. The relative quantification between ACBP and $\beta$-actin transcript in all cDNAs were calculated from comparative CT method using a FTC-3000 real-time cycler System Software (Funglyn Biotech, Toronto, Canada), to maintain repeatability, the baseline was set autoscale by the software.

\section{G. Tissue Expression Analysis}

Expressions of Oma-ACBP mRNA in tissues were demonstrated by quantitative real-time PCR. The samples of untreated from the gonad, ovary, liver, heart, brain, cheek, 
intestine, muscle, eye and spleen were collected. The samples of dietary challenge from liver, intestine and muscle were collected, starvation challenge from liver, intestine and muscle were collected. Total RNA at $500 \mathrm{ng}$ was reverse transcribed to the first strand cDNA, a pairs of primers $(\mathrm{P}-\mathrm{QF}$ and P-QR) was used amplify a PCR product, and the Primers(actinF and actinR) were used to amplify the $\beta$-actin fragment, The real-time PCR reaction was the same as that described above.

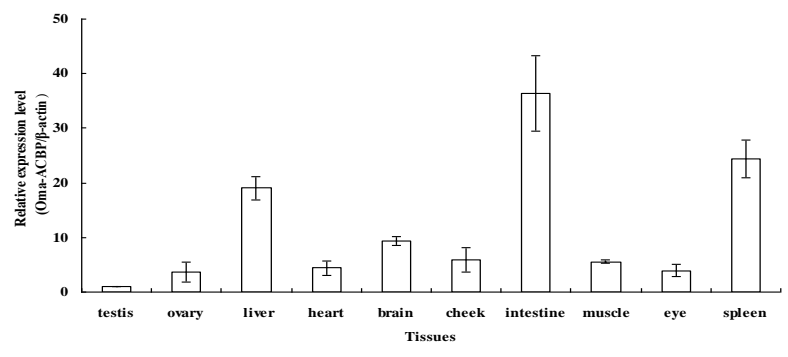

Fig. 3. Analysis of $O m a-A C B P$ expression in different tissues by quantitative real-time RT-PCR. Each bar represents the mean $\pm \mathrm{SD}$ (standard deviation), $n=3$.

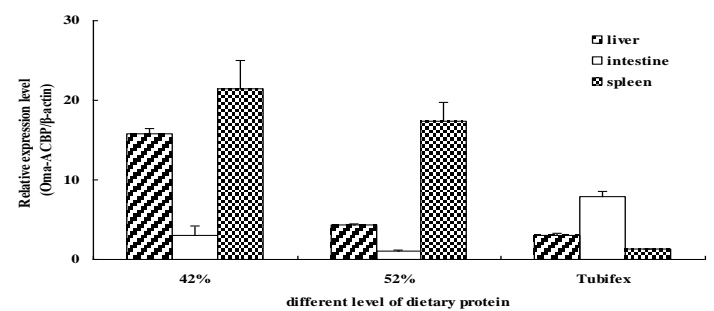

Fig. 4. Analysis of Oma-ACBP expression in dietary challenge by quantitative real-time RT-PCR at the protein level of $42 \%, 52 \%$.

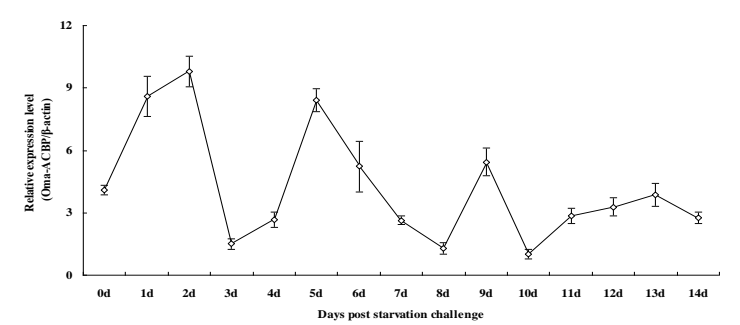

Fig. 5. Analysis of Oma-ACBP expression post starvation challenge from 0day to 14day. Each bar represents the mean $\pm \mathrm{SD}$ (standard deviation), $n=3$.

\section{RESUlTS}

\section{A. Cloning of Oma-ACBP}

Based on the searched data of GeneBank, specific primers(Fig. 1) were designed for ACBP gene of Onychostoma macrolepis. Amplification of fish testis cDNA with PF1/ PR1 primers yielded cDNA fragments of $O m a-A C B P$, the sequence of 5' end and 3' end was determined by 5'RACE and 3'RACE method, and put together to make a full length of Oma-ACBP. The full Oma-ACBP cDNA(JN254628) was 503 bp long(excluding the poly-A tail) and comprised $37 \mathrm{bp}$ of the $5^{\prime}$-Untranslated Regions(UTR), 267 bp of the coding sequence(CDS) encoding a 88 amino acid proteins, and $199 \mathrm{bp}$ of the 3'-Untranslated Regions(UTR), showed in Figure 6. An amino-acid sequence alignment including representatives of the various groups and species within ACBP family was prepared by Clustal $\mathrm{W}$ program, sequence alignments showed that the fish ACBP proteins share extensive sequence similarity with other species(Fig. 7 and Fig. 8).

61

12

18

24

1

30

42

48 aagcacatctttataacagactgaaacagctacaaccatgtctgaggctgagtttcagaa M S E A E F Q K

agcagcagaggaggtcaaacagctgaaagcgaaaccatcagacgctgagatgctggaaat $\begin{array}{lllllllllllllllllllll}\text { A } & A & E & E & V & K & Q & L & K & A & K & P & S & D & A & E & M & L & E & I\end{array}$ ttatagtctgtacaaacaggccaccgtaggagatgttaacacagctcgaccgggcatgtt

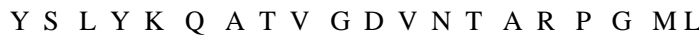
agatttcactggcaaggccaaatgggaagcttgggaggccaaggaaggtatgagtaagga

D F T G K A K W E A W E A K E G M S K D tgatgctacaaaagcatacatcgctaaggtagaagagctgaaggggaaatacggaatcga

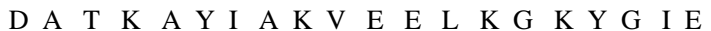
atagacggaacccatcatggecagettgectttacetgtactgtcetcccataaagcgec

$*$

tttaggcctccagtgtgtccctcacaaaggtgttacagttacgctgtagcatggagact

cttttctgtgtgagagaataggcacattcctcacaggccaagagaaatcgtccaccagta accatgtagttaaacgccetgat

Fig. 6. The full length cDNAs and deduced amino acid sequences of Oma-ACBP

TABLE I: PROTEIN SIMILARITIES OF OMA-ACBP wITH OTHER SPECIES

\begin{tabular}{|c|c|c|c|c|c|}
\hline Species & Score & Expected value & Identities $(\%)$ & Positives $(\%)$ & GenBank No. \\
\hline Cyprinus carpio & 167 & $2.00 \mathrm{E}-53$ & $83 / 87(95 \%)$ & $86 / 87(99 \%)$ & AAT00460 \\
\hline Carassius auratus & 167 & $2.00 \mathrm{E}-53$ & $83 / 87(95 \%)$ & $86 / 87(99 \%)$ & BAJ83550 \\
\hline Danio rerio & 162 & $2.00 \mathrm{E}-51$ & $80 / 87(92 \%)$ & $85 / 87(98 \%)$ & AAH62845 \\
\hline Epinephelus coioides & 152 & $2.00 \mathrm{E}-47$ & $74 / 87(85 \%)$ & $82 / 87(94 \%)$ & ABW04128 \\
\hline Meleagris gallopavo & 145 & $7.00 \mathrm{E}-45$ & $70 / 87(80 \%)$ & $79 / 87(91 \%)$ & XP003207735 \\
\hline Taeniopygia guttata & 145 & $1.00 \mathrm{E}-44$ & $71 / 87(82 \%)$ & $78 / 87(90 \%)$ & XP002197380 \\
\hline mallard ducks & 143 & $8.00 \mathrm{E}-44$ & $69 / 86(80 \%)$ & $78 / 86(91 \%)$ & AAC06123 \\
\hline
\end{tabular}

\section{A. Phylogenetic Analysis of Oma-ACBP with Other Species}

To examine the relationship of fish sequences to the various members of the ACBP family, a phylogenetic tree was constructed using the neighbor-joining method (NJ) with the amino acid sequences of fish and other known ACBP.
Phylogenetic analysis revealed that the $O m a-A C B P$ formed an exclusive group, One group consisted of fish ACBP(Carassius auratus, Cyprinus carpio, Danio rerio. Ictalurus punctatus, Epinephelus coioides, Oncorhynchus mykiss, Salmo salar), group another consisted of mammal and amphibian ACBP (Homo sapiens, Xenopus laevis; Fig. $9)$. 


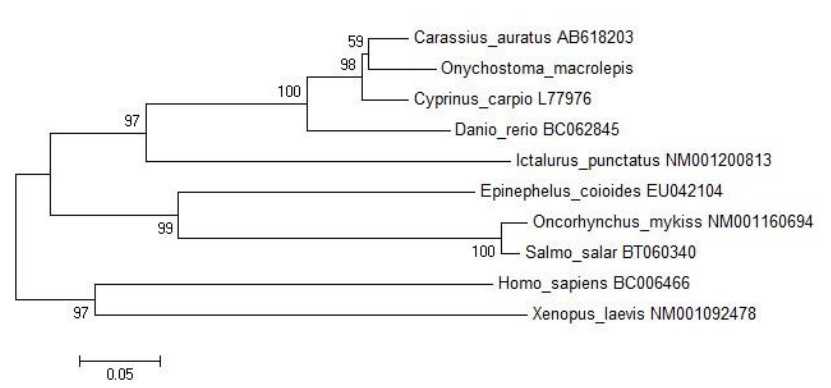

Fig. 7. Phylogenetic analysis of Oma-ACBP with other known ACBPs of sequences from GenBank, The phylogenetic tree was produced with MEGA 4.0 and Clustal $\mathrm{X}$.

\section{B. qRT-PCR Analysis of Oma-ACBP Expression}

Expression of $O m a-A C B P$ in different tissues are shown in Fig.3. In this study, a pair of primers (P-QF and P-QR, Fig.1) were used to amplify a $144 \mathrm{bp}$ fragment. The Oma-ACBP mRNA was highly expressed in intestine, spleen and liver, but weakly in testis, ovary, heart, brain, cheek, muscle and eye.

In order to clarify the effects between dietary challenge and Oma-ACBP expression, the totle RNA were extracted from intestine, spleen and liver was extracted at $5 \mathrm{hr}$ post-challenged in dietary protein of $42 \%$ group and $52 \%$ group, diet of Tubifex (Limnodrilus hoffmeisteri) as the control group(Fig.4). The results showed that Oma-ACBP were affected by the protein content of diet. Statistical analysis showed that there was difference of $O m a-A C B P$ transcript post dietary challenge between $42 \%$ group and $52 \%$-Tubifex groups in liver $(p<0.05), 42-52 \%$ groups and Tubifex group in intestine $(p<0.05), 42-52 \%$ groups and Tubifex group in spleen $(p<0.05)$. The dietary challenge suggest that long-term change of dietary protein could affect the expression of Oma-ACBP at the mRNA level in intestine, spleen and liver.

The expression of Oma-ACBP was detected post starvation challenge, the expression was weakly expressed from $5 \mathrm{~d}$ to $8 \mathrm{~d}$, and highly expressed from $3 \mathrm{~d}$ to $5 \mathrm{~d}$, the expression from $11 \mathrm{~d}$ to $14 \mathrm{~d}$ was stabilizing (Fig. 5).

\section{DISCUSSION}

ACBP is believed to play an important role in intracellular acyl-CoA transport and pool formation [15]. So, the study of how these lipids are metabolized and transported in the cells is crucialto understand these processes. In the present study, a novel ACBP cDNA from Onychostoma macrolepis that encodes 88 amino acids was identified and its expression of tissues suggests that this protein may be associated with sevral basal cellular functions in the fish.

The expression of Oma-ACBP expressed intermediately in intestine, spleen and liver, weakly expressed in testis, ovary, heart, brain, cheek, muscle and eye. In animals, ACBP is also ubiquitously expressed in various tissues such as the intestine, the testis, the brain, and the liver [4]-[16]. Recently, bacterial challenge implicated that ACBP may have a relationship between regulator of immune and Infection responses in shrimp intestine [5]. However, in rainbow trout, ACBP could be used as markers to prevent excess muscle fat accumulation [17]. Our datas show that ACBP is essential to all organizations, recently, the Oma-ACBP mRNA is highly expressed in intestine, this may indicate that mRNA expression of ACBP is up regulated to adjust to intensity of fat metabolism in intestine.

In insect, the Rhodnius prolixus ACBP gene expression increased in the first day after blood meal and then decreased to unfed levels in the seventh day after meal, and ACBP gene was expressed in all analyzed tissues and quantitative PCR showed that expression was highest in posterior midgut [13]. In rats fasting for 24 hours significantly decreased tissue levels of ACBP in the liver, whereas feeding of a high-fat diet for 48 hours caused ACBP levels to increase [18]. In rainbow trout, the grouth rate of domesticated species were higher than wild species, ACBP expressinon changed in muscle and liver, the genes of domesticated fish mainly for the regulation and control, and a strong ability to control cell division and regulation of structural genes [19]. In the present study, there were obvious difference of Oma-ACBP transcript post dietary challenge between $42 \%$ and control group in liver and spleen, $52 \%$ and control group in intestine; There was no significant difference between 52\% and control group in liver, $42 \%$ and $52 \%$ in intestine and spleen. The metabolism was active during the dietary protein at the content of $42 \%$ in liver and spleen. This may indicate that through changes of dietary protein content, ACBP expressions of tissue were regulated, thereby changing the metabolic intensity, the level expression of ACBP may serve as an indicator of feed selection, the expression patterns in the Onychostoma macrolepis remain to be further studied. On the other hand, the ACBP over expression affects metabolic responses to diets with distinct difference in their fatty acid chain lengths, the ACBP-induced tissue-specific regulation of expression of PPARs and SREBP [20].

In mice, the ACBP expression level decreased significantly after 24 hours of hunger, and then feeded, the ACBP expression level reach the minimum point after 12 hours, the the ACBP expression returned to normal levels after 24 hours [16]. Another study, cute fasting dramatically reduces $\mathrm{ACBP} / \mathrm{DBI} \mathrm{mRNA}$ levels in the hypothalamus and the ependyma bordering the third and lateral ventricles [21]. In Strongylocentrotus internedius, ACBP(HM208169) was weekly expressed in gonads of female sea urchins after 2-day starvation, the expression of ACBP(HM208170) in gonads female urchins was weak after 2-day starvation, turned to high after 4-day starvation, and kept high from 13th to 30th starvation [22]. In the present study, the expression of Oma-ACBP was impacted by the time of hunger extension, this may indicate that fish adopt to the stress response of starvation by altering gene expression.

In summary, this study reports the first cloning the ACBP gene(JN254628), from Onychostoma macrolepis. We obtained 503 bp long sequences (excluding the poly-A tail), $267 \mathrm{bp}$ of the coding sequence(CDS) encoding a 88 amino acid proteins. By quantitative real-time PCR, we showed a significant changes in mRNA expression of two different conditions showing similarity in organs of Onychostoma macrolepis. The expression analysis of Oma-ACBP indicated that it play a key role in metabolism system. So, this study provides another insight on the gene of Onychostoma macrolepis, it has a role in the study of molecular biology and 
metabolism of ACBP. However, further studies are needed to define mechanisms for Lipids metabolism and the relevant impact of FABP transcription conditions in Onychostoma macrolepis.

\section{ACKNOWLEDGMENT}

The authors want to acknowledge the skilful technical assistance of Dr. Hongxia Hu and Dr. Zhaohui Tian(lab of Agriculture, Beijing Agricultural Biotechnology Research Center).

\section{REFERENCES}

[1] N. J. Faergeman, M. Wadum, S. Feddersen, M. Burton, B. B Kragelund, and J. Knudsen, "Acyl-CoA binding proteins; structural and functional conservation over 2000 MYA," Mol. Cell. Biochem., vol. 299, pp. 55-65, May 2007.

[2] M. Burton, T. M. Rose, N. J. Færgeman, and J. Knudsen, "Evolution of the acyl-CoA binding protein(ACBP)," Biochem. J., vol. 392, pp. 299-307, July 2007.

[3] J. Rosendal, P. Ertbjerg, and J. Knudsen, "Characterization of ligand binding to acyl-CoA-binding protein," Biochem. J., vol. 290, pp. 321-326, March 1993.

[4] M. A. Bezerra, D. Majerowicz, L. A. M. Grillo, H. Tremonte, C. B Almeida, and G. R. C. Braz, "Serotonin regulates an acyl-CoA-binding protein(ACBP) gene expression in the midgut of Rhodnius prolixus," Insect Biochem Molec., vol. 40, pp. 119-125, February 2010.

[5] Q. Ren, Z. Q. Du, X. F. Zhao, and J. X. Wang, “An acyl-CoA-binding protein(FcACBP) and a fatty acid binding protein(FcFABP)respond to microbial infection in Chinese white shrimp, Fenneropenaeus chinensis," Fish Shellfish Immun., vol. 27, pp. 739-747, December 2009.

[6] B. Gaigg, T. B. F. Neergaard, R. Schneiter, J. K. Hansen, N. J. Færgeman, and N. A. Jensen, "Depletion of acyl-coenzyme-A-binding protein affects sphingolipid synthesis and causes vesicle accumulation and membrane defects in Saccharomyces cerevisiae," Mol. Biol. Cell., vol. 12, pp. 1147-1160, April 2001.

[7] T. Solstad, L. Fismen, H. Garberg, and K. E. Fladmark, "Identification of a novel phosphorylation site of acyl-CoA binding protein(ACBP) in nodularin-induced apoptotic hepatocytes," Exp. Cell Res., vol. 314, pp. 2141-2149, June 2008

[8] N. J Faergeman, S. Feddersen, J. K. Christiansen, M. K. Larsen, R. Schneiter and C. Ungermann, "Acyl-CoA-binding protein, Acb1p, is required for normal vacuole function and ceramide synthesis in Saccharomyces cerevisiae," Biochem. J., vol. 380, pp. 907-918, June 2004.

[9] G. P. Owens, A. K. Sinha, J. M. Sikela, and W. E. Hahn, "Sequence and expression of the murine diazepam binding inhibitor," Mol. Brain Res. vol. 6, pp. 101-108, November 1989.

[10] M. Metzner, K. P. Ruecknagel, J. Knudsen, G. Kuellertz, F. Mueller-Uri, and B. Diettrich, "Isolation and characterization of two acyl-CoA-binding proteins from proembryogenic masses of Digitalis lanata Ehrh," Planta. , vol. 210, pp. 683-685, August 2000.

[11] N. H. Putnam, M. Srivastava, U. Hellsten, B. Dirks, J. Chapman, and A.Salamov, "Sea anemone genome reveals ancestral eumetazoan gene repertoire and genomic organization," Science., vol. 317, pp. 86-94, July 2007.

[12] R. L. Strausberg, E. A. Feingold, L. H. Grouse, J. G. Derge, R. D. Klausner, and F. S. Collins, "Generation and initial analysis of more than 15,000 full-length human and mouse cDNA sequences," in Proc. Natl. Acad. Sci., USA, vol. 99, pp. 16899-16903, December 2002.

[13] F. Chen, Y. Lee, Y. 1. Jiang, S. 1. Wang, E. Peatman, and J. Abernathy, "Identification and characterization of full-length cDNAs in channel catfish (Ictalurus punctatus) and blue catfish (Ictalurus furcatus)," PLoS ONE., vol. 5, pp. 11546, April 2010.

[14] X. F. Yang, S. G. Xu, Y. Z. Wang, and G. Q. Yang, "Cloning, characterization and expression analysis of DEAD-box family vasa gene, in Largescale shoveljaw fish(Onychostoma macrolepis)," in Proc. 5th International Conference on Bioinformatics and Biomedical Engineering, Wuhan, 2011, pp. 237-241.

[15] J. Knudsen, M. V. Jensen, N. J. Fsgmaeligrgeman, T. B. F. Neergaard, and B. Gaigg, "Role of acylCoA binding protein in acylCoA transport, metabolism and cell signaling," Mol Cell Biochem., vol. 192, pp. 95-103, February 1999.

[16] M. B. Sandberg, M. Bloksgaard, D. Duran-Sandoval, C. Duval, B. Staels and S. Mandrup, "The gene encoding acyl-CoA-binding protein is subject to metabolic regulation by both sterol regulatory element-binding protein and peroxisome proliferator-activated receptor $\alpha$ in hepatocytes," J. Biol. Chem., vol. 277, pp. 26821-26830, February 2005.

[17] C.-I. Kolditz et al., "Changes induced by dietary energy intake and divergent selection for muscle fat content in rainbow trout (Oncorhynchus mykiss), assessed by transcriptome and proteome analysis of the liver," BMC Genomics., vol. 9, pp. 47-64, October 2008.

[18] N. J. Færgeman, M. Wadum, S. Feddersen, M. Burton, B. B. Kragelund, and Jens Knudsen, "Acyl-CoA binding proteins, tructural and functional conservation over 2000 MYA," Mol. Cell. Biochem., vol. 299, pp. 55-65, September 2007.

[19] W. Tymchuk, D. Sakhrani, and R. Devlin, "Domestication causes large-scale effects on gene expression in rainbow trout: Analysis of muscle, liver and brain transcriptomes," Gen. Comp. Endocr., vol. 164, pp. 195-183, May 2009.

[20] S. Oikari, T. Ahtialansaari, A. Huotari, K. Kiehne, U. R. Fölsch, and S. Wolffram, "Effect of medium- and long-chain fatty acid diets on PPAR and SREBP-1 expression and glucose homeostasis in ACBP-overexpressing transgenic rats," Acta. Physiol., vol. 194, pp. 57-65, April 2008.

[21] V. Compère et al., "Acute food deprivation reduces expression of diazepam-binding inhibitor, the precursor of the anorexigenic octadecaneuropeptide ODN, in mouse glial cells," Mol. Endocrinol., vol. 44, pp. 295, March 2010.

[22] X. F. Yang, Y. Q. Chang, and H. Han, "Acyl-CoA binding protein(ACBP) encoding genes in the sea urchin Strongylocentrotus internedius," in Proc. 9th International Marine Biotechnology Conference, Qingdao, 2010, pp. 67.

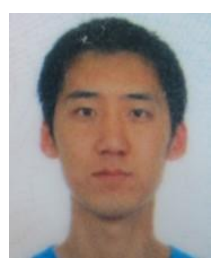

Xiaofei Yang was born in 1982, Beijing, China. From 2003 to 2007 in Dalian Ocean University, he received his bachelor degree of aquaculture. From 2007 to 2010 in Dalian Ocean University, he obtained his master degree of aquaculture and biotechnology. From 2010 to 2013 in Beijing Fisheries Research Institute, the main research Including cold water fish breeding and biotechnology.

His current job location on Cold-water fish breeding and biotechnology. His article Include: "Acyl-CoA binding protein (ACBP) encoding genes in the sea urchin Strongylocentrotus internedius," and "Amino acid and fatty acid profiles in early stages of egg and larvae of steelhead trout(Oncorhynchus Mykiss)". 